\title{
The lipidome and proteome of oil bodies from Helianthus annuus (common sunflower)
}

\author{
Samuel Furse • Susan Liddell • Catharine A. Ortori • \\ Huw Williams • D. Cameron Neylon • David J. Scott • \\ David A. Barrett • David A. Gray
}

Received: 10 November 2012 / Accepted: 28 December 2012 /Published online: 26 January 2013

(C) Springer-Verlag Berlin Heidelberg 2013

\begin{abstract}
In this paper we report the molecular profiling, lipidome and proteome, of the plant organelle known as an oil body $(\mathrm{OB})$. The $\mathrm{OB}$ is remarkable in that it is able to perform its biological role (storage of triglycerides) whilst resisting the physical stresses caused by changes during desiccation (dehydration) and germination (rehydration). The molecular profile that confers such extraordinary physical stability on OBs was determined using a combination of ${ }^{31} \mathrm{P} /{ }^{1} \mathrm{H}$ nuclear magnetic resonance (NMR), high-resolution
\end{abstract}

Electronic supplementary material The online version of this article (doi:10.1007/s12154-012-0090-1) contains supplementary material, which is available to authorized users.

S. Furse $(\bowtie) \cdot$ S. Liddell $\cdot$ D. A. Gray $(\bowtie)$

School of Biosciences, University of Nottingham,

College Lane, Sutton Bonington, Nottinghamshire LE12 5RD, UK

e-mail: Samuel.Furse@nottingham.ac.uk

e-mail: David.Gray@nottingham.ac.uk

S. Furse

e-mail:samuel@samuelfurse.com

C. A. Ortori · D. A. Barrett

Centre for Analytical Bioscience, School of Pharmacy, University

of Nottingham, University Park, Nottingham NG7 2RD, UK

H. Williams

Centre for Biomolecular Sciences, University of Nottingham,

University Park, Nottingham NG7 2RD, UK

D. C. Neylon

ISIS Spallation Neutron Source, STFC, Rutherford Appleton

Laboratory, Harwell Science and Innovation Campus,

Harwell, Oxon OX11 0QX, UK

D. J. Scott

National Centre for Macromolecular Hydrodynamics,

University of Nottingham, College Lane, Sutton Bonington,

Nottinghamshire LE12 5RD, UK mass spectrometry and nominal mass-tandem mass spectrometry for the lipidome, and gel-electrophoresischromatography-tandem mass spectrometry for the proteome. The integrity of the procedure for isolating OBs was supported by physical evidence from small-angle neutron-scattering experiments. Suppression of lipase activity was crucial in determining the lipidome. There is conclusive evidence that the latter is dominated by phosphatidylcholine $(\sim 60 \%)$ and phosphatidylinositol $(\sim 20 \%)$, with a variety of other head groups ( $\sim 20 \%)$. The fatty acid profile of the surface monolayer comprised palmitic, linoleic and oleic acids (2:1:0.25, ${ }^{1} \mathrm{H}$ NMR) with only traces of other fatty acids (C24:0, C22:0, C18:0, C18:3, C16:2; by MS). The proteome is rich in oleosins $(78 \%)$ with the remainder being made up of caleosins and steroleosins. These data are sufficiently detailed to inform an update of the understood model of this organelle and can be used to inform the use of such components in a range of molecular biological, biotechnological and food industry applications. The techniques used in this study for profiling the lipidome throw a new light on the lipid profile of plant cellular compartments.

Keywords Lipidome Proteome $\cdot$ Lipase inhibition $\cdot$ NMR · MS · SANS

$\begin{array}{ll}\begin{array}{l}\text { Abbreviations } \\ \text { CET }\end{array} & \begin{array}{l}\text { Mixture of chloroform, ethanol and } \\ \text { triethylamine [3:1:1] }\end{array} \\ \text { DAG } & \begin{array}{l}\text { Diacylglyceride } \\ \text { HMBC }\end{array} \\ \text { Hetero-nuclear multiple-bond correlation } \\ \text { HMQC } & \begin{array}{l}\text { Hetero-nuclear single quantum } \\ \text { spectroscopy }\end{array} \\ \text { HRMS } & \text { High-resolution mass spectrometry } \\ \text { GeLC-MS/MS } & \end{array}$


Gel-electrophoresis-chromatographytandem mass spectrometry

$\begin{array}{ll}\text { MS }^{\mathrm{n}} \text { MS/MS } & \text { Nominal mass-tandem mass spectrometry } \\ \text { NMR } & \text { Nuclear magnetic resonance } \\ \text { MS } & \text { Mass spectrometry } \\ \text { PA } & \text { Phosphatidic acid } \\ \text { PB } & \text { Phosphatidylbutanol } \\ \text { PC } & \text { Phosphatidylcholine } \\ \text { PE } & \text { Phosphatidylethanolamine } \\ \text { PG } & \text { Phosphatidylglycerol } \\ \text { PI } & \text { Phosphatidylinositol } \\ \text { PI-4-P } & \text { Phosphatidylinositol 4-phosphate } \\ \text { PS } & \text { Phosphatidylserine } \\ \text { PT } & \text { Phosphatidylthreonine } \\ \text { SANS } & \text { Small-angle neutron-scattering } \\ \text { SLD } & \text { Scattering length density } \\ \text { TOCSY } & \text { Total correlation spectroscopy } \\ \text { TG } & \text { Triglyceride }\end{array}$

\section{Introduction}

Molecular profiling ('omics') is beginning to reveal the variety of molecular species in biological systems. A relatively recent innovation is profiling of the lipid fraction, referred to as lipidomics [16, 17, 22, 54]. The applications of this chemical approach are increasing rapidly as a direct result of the powerful insights it provides into determining molecular composition. Lipidomics is currently being used not only to probe the lipid composition of biological systems but also some of the molecular changes during metabolic processes, and disease [2, 46, 62]. Proteomic studies are also used for tracking disease [19,27], with some work on proteinaceous systems with a mechanical role [10]. Furthermore, as the physical properties and behaviour of the lipids and proteins in biological systems start to become apparent at a molecular level $[1,11,26,40,59,63,72]$, the applicability of molecular profiling data in understanding the molecular construction of organelles increases $[18,73]$. However, in order to produce an accurate molecular profile of an organelle, there is a clear need for the use of diagnostic orthogonal chemical techniques.

One cellular compartment found in plants, about which there is some understanding of the biological role but relatively little about the structure or physical properties, is the seed-specific oil body (OB). OBs have evolved the function of a biological repository for triglycerides and typically represent about $40 \%$ of the mass of the cotyledon in (desiccating) oleaginous seeds [43]. They are 0.5-2.0 $\mu \mathrm{m}$ in diameter $[25,29]$ with a postulated structure of a monolayer of amphiphilic species covering a mass of triglycerides $[29,34]$. Evidence to date suggests that the monolayer that forms the surface of the $\mathrm{OB}$ comprises phospholipids and proteins from a relatively small group of protein families [28-31, 66]. However, it has not yet been possible to be precise about the molecular composition or the assembly it forms, as no comprehensive studies of molecular composition have been published, nor have there been any physical studies of purified isolated OBs.

The structure of these organelles remains stable and controlled throughout the dehydration associated with desiccation and the rehydration associated with germination [43], suggesting that they are able to resist the welldocumented changes that occur in model lipid [37, 38, 50] and protein $[20,58,71]$ systems on drastic changes in hydration. This remarkable stability makes OBs a desirable research interest, not only in terms of understanding the molecular biology of processes like germination [43] but also in biotechnological engineering, such as generating recombinant therapeutics $[3,7,56]$ and as an adjuvant for vaccines [15]. It has also been possible to use OBs as a means for recovering and recycling immobilised enzymes $[9,35,36]$. Recent research in food science and technology suggests that OBs have potential as an ingredient in industrial production of edible emulsions [23, 24, 39, 47]. This range of interests highlights the importance of understanding the physical behaviour and properties of OBs and their components.

We chose to analyse OBs from Helianthus annuus (common sunflower) in order to provide an insight into this representative plant system. This species is germane to industrial-scale food industry applications as it is a viable crop for industrial applications. Also, the seed material presents a low allergen risk. Importantly, the OBs from this species are not well characterised to date. We used smallangle neutron-scattering (SANS) to assess the purity of the OBs isolated and to inform the details of improved protocols for isolating OBs from raw seeds. Molecular profiling of the organelle comprised lipidomic and proteomic analyses. The lipidome was profiled using ${ }^{31} \mathrm{P}$ nuclear magnetic resonance (NMR) using an $800 \mathrm{MHz}$ magnet, HRMS, and MSn MS/ MS. We have also developed a novel method of analysis using NMR that can identify a lipid biomarker even when it is a minor component in a complicated mixture of lipids. We used GeLC-MS/MS to identify components of the protein fraction and densitometry for identifying their relative proportions.

\section{Experimental section}

All solvents used were HPLC-grade and were bought from Sigma Aldrich Ltd (Gillingham, Dorset, UK), as were all fine chemicals and deuteriated solvents, unless otherwise stated. Lipase inhibitors, except 2-butoxyphenylboronic acid (BPBA) and $n$-butanol, were bought from Tocris 
Biosciences Ltd (Bristol, Somerset, UK), and lipid standards were bought from Avanti Polar lipids (Alabaster, Alabama, USA). All chemicals were used as supplied. Sodium dodecyl sulphate-polyacrylamide gel electrophoresis (SDSPAGE) was carried out using equipment and consumables from Bio-Rad Laboratories Ltd. (Hemel Hempstead, Hertfordshire, UK). Protease inhibitors 'cOmplete', in tablet form were purchased from Roche Diagnostics Ltd (Burgess Hill, Sussex, UK). De-hulled H. annuus seeds (2011 season) were bought from the Goldene Mühle GmbH (Garrel, Lower Saxony, Germany). Seed material was stored at $\sim 10{ }^{\circ} \mathrm{C}$ in an airtight container and used within a month of purchase.

Oil body isolation De-hulled H. annuus seeds (100.0 g) were mixed with a solution of lipase inhibitors (suspension in $n$-butanol [5 mL] of FIPI, $5 \mathrm{mg}$; D609, $10 \mathrm{mg}$; U73122, $10 \mathrm{mg}$; BPBA, $1 \mathrm{~g})$ and Tris-base $(0.1 \mathrm{M}, \mathrm{pH} 7.5,200 \mathrm{~mL}$, cOmplete ULTRA protease inhibitor tablets [used as directed]) and ground using a Silverson high-shear mixer L $5 \mathrm{M}$ (Silverson Ltd, Chesham, Buckinghamshire, UK), operated at $<2 \mathrm{krpm}$ ) with the dilution of the mixture (addition of $200 \mathrm{~mL}$ Tris-base $0 \cdot 1 \mathrm{M}, \mathrm{pH} 7.5$ ) with successively narrowing mesh sizes of the homogeniser work head $(5 \mathrm{~mm}$ mesh, then $2.5 \mathrm{~mm}$, then $1.5 \mathrm{~mm}$ ). The resulting suspension was made up to a total volume of $1.4 \mathrm{~L}$ (Tris-base $0 \cdot 1 \mathrm{M}, \mathrm{pH} 7.5$, total volume $1 \mathrm{~L}$, made in advance and chilled to $<10{ }^{\circ} \mathrm{C}$ ) and the mixture fractionated by centrifugation $(9,950 \times \mathrm{g}$, $20 \mathrm{~min}, 4^{\circ} \mathrm{C}$ ). The uppermost layer was removed, resuspended in Tris-base $(0.01 \mathrm{M}, \mathrm{pH} 7.5, \sim 4: 1 v / v)$ and fractionated by centrifugation $\left(2,800 \times g, 20 \mathrm{~min}, 4{ }^{\circ} \mathrm{C}\right)$. The uppermost layer was removed, resuspended in a series of aqueous solutions $(\sim 4: 1 \mathrm{v} / \mathrm{v})$ before centrifugation at each step $\left(2,800 \times g, 20 \mathrm{~min}, 4^{\circ} \mathrm{C}\right)$. The aqueous suspensions used were: Tween $20(1 \% \mathrm{v} / \mathrm{v}$, with Tris-base $0.01 \mathrm{M}, \mathrm{pH} 7.5$, $\left.\mathrm{ddH}_{2} \mathrm{O}\right), \mathrm{NaCl}(2 \mathrm{M}$, with Tris-base $0.01 \mathrm{M}, \mathrm{pH} 7.5$, $\mathrm{ddH}_{2} \mathrm{O}$ ), urea (8 M, with Tris-base $0.01 \mathrm{M}, \mathrm{pH} 7.5$, $\left.\mathrm{ddH}_{2} \mathrm{O}\right)$, and finally Tris-base (0.01 M, pH7.5). The suspensions in aqueous urea were agitated at room temperature for $30 \mathrm{~min}$, before centrifugation.

Oil body fractionation Immediately after isolation, the OBs were suspended in ethanol $(8: 1 v / v)$ and the internal phosphorus standard added (lyso-phosphatidylglycerol, known mass of $2.5-4.5 \mathrm{mg})$. The solvents were then removed under reduced pressure $(2 \times 200 \mathrm{~mL}$ ethanol $)$ and the remaining material washed with petroleum spirit $(3 \times 300 \mathrm{~mL}$, $50 \mathrm{mmHg}$, glass sinter). The combined solutions were concentrated in vacuo to give the triglyceride (oil) fraction. The retentate was suspended (chloroform/ethanol/triethylamine, 3:1:1 [CET], $300 \mathrm{~mL}$ ), sonicated (Ultrasonicator USC1700D, VWR (Lutterworth, Leicestershire, UK), power $9,25{ }^{\circ} \mathrm{C}, 15 \mathrm{~min}$ ), and washed (CET, $2 \times 100 \mathrm{~mL}$,
$50 \mathrm{mmHg}$, glass sinter). The retentate was washed lightly with chloroform. The combined CET solutions and chloroform wash were concentrated in vacuo to give the lipid fraction. The remaining solid was dried in vacuo to give what is referred to as the protein fraction. The mass of protein was measured using the Bradford Assay. Details of spectral techniques and protein analysis can be found in the Electronic Supplementary Material.

\section{Results}

OB isolation and SANS

Traditionally, OBs have been isolated by gentle mechanical grinding of mature seeds in an aqueous medium, followed by centrifugation $[66,70]$. A similar procedure was used here, with a number of important adaptations. Several steps are required to remove extraneous protein (particularly $11 \mathrm{~S}$ storage [helianthinin] and $2 \mathrm{~S}$ ribosomal proteins) and extraneous lipophilic material satisfactorily. We therefore used a modified version of the previously reported methods. In the preparation used in this study, the OBs are centrifuged immediately after grinding and were then resuspended in a series of aqueous media before centrifugation.

In order to verify the efficacy of these preparation and purification steps for isolating OBs, and to provide an independent check of the proteins observed in GeLC-MS/MS analysis of the OB protein mixtures that are postulated to be extraneous (see below), we elected to use contrast-variation SANS to determine the compartmentalisation and spatial arrangement of system components on the micron scale.

Both the crude and purified OB samples (see Supplementary Information) were prepared in $10 \% \mathrm{D}_{2} \mathrm{O}$ (to match the SLD of lipid component and highlight any protein signal) $40 \% \mathrm{D}_{2} \mathrm{O}$ (to match the protein and highlight lipid) and $90 \% \mathrm{D}_{2} \mathrm{O}$ (in which both species would be visible). The scattering patterns obtained are broadly compatible with a model of large poly-disperse spheres with sizes on the micron range of poly-dispersity index of around $60-70 \%$.

In the pattern from the crude preparation in $90 \% \mathrm{D}_{2} \mathrm{O}$, an additional feature was present, not seen in the $40 \%$ pattern, suggesting a significant contribution from protein (Fig. 1a), that was absent in preparations designed to remove extraneous material (Fig. 1b). The data recorded at $10 \% \mathrm{D}_{2} \mathrm{O}$ (lipid matched) for the crude preparation suggest a mono-dispersed but small protein species that could be modelled as an isolated ellipse (Fig. 1c). The fits used in Fig. 1 were consistent with a Gaussian polydisperse sphere model with scaled OB volume fractions. These scattering patterns are therefore reliable indicators of the system's spatial arrangement, even at higher polydispersities. This suggested that either the crude 
preparation had a contaminant that was a free protein, or that a significant quantity of protein is present in the OBs as isolated free-floating species. The modelled shape is consistent with the structural data for $11 \mathrm{~S}$ globulin (helianthinin) from formative studies $[52,55]$.

a
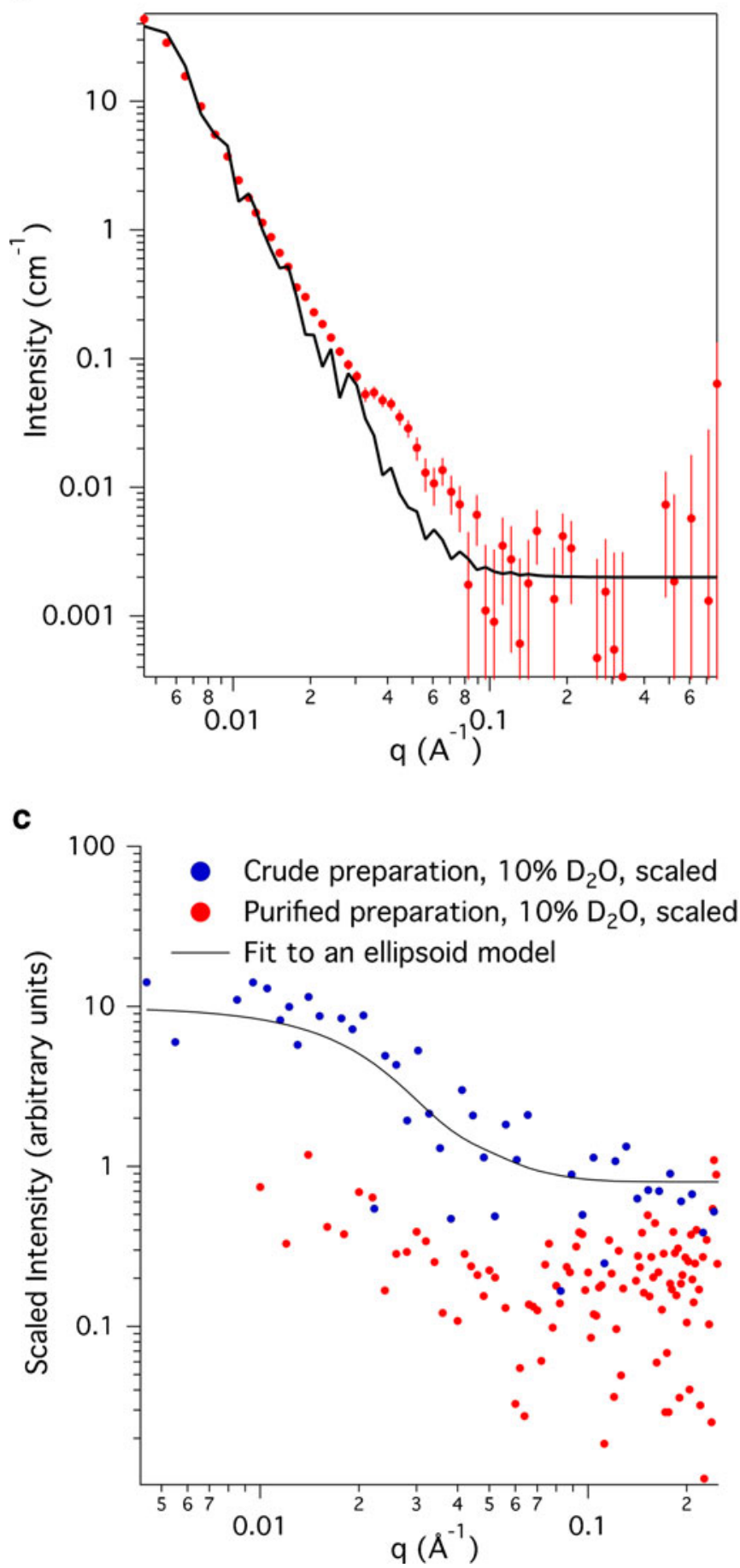

Fig. 1 SANS scattering of OB systems containing free protein (a) and not (b). c SANS of OB samples with a lipid-matching concentration of exchangeable deuterium (10\%). The crude preparation (blue) shows a
To determine the source of the signal a sample of more thoroughly purified OBs was analysed at high concentrations with the same three contrasts. In the $90 \% \mathrm{D}_{2} \mathrm{O}$ sample where both protein and lipid should be visible, the (additional) feature visible in data from the crude

b

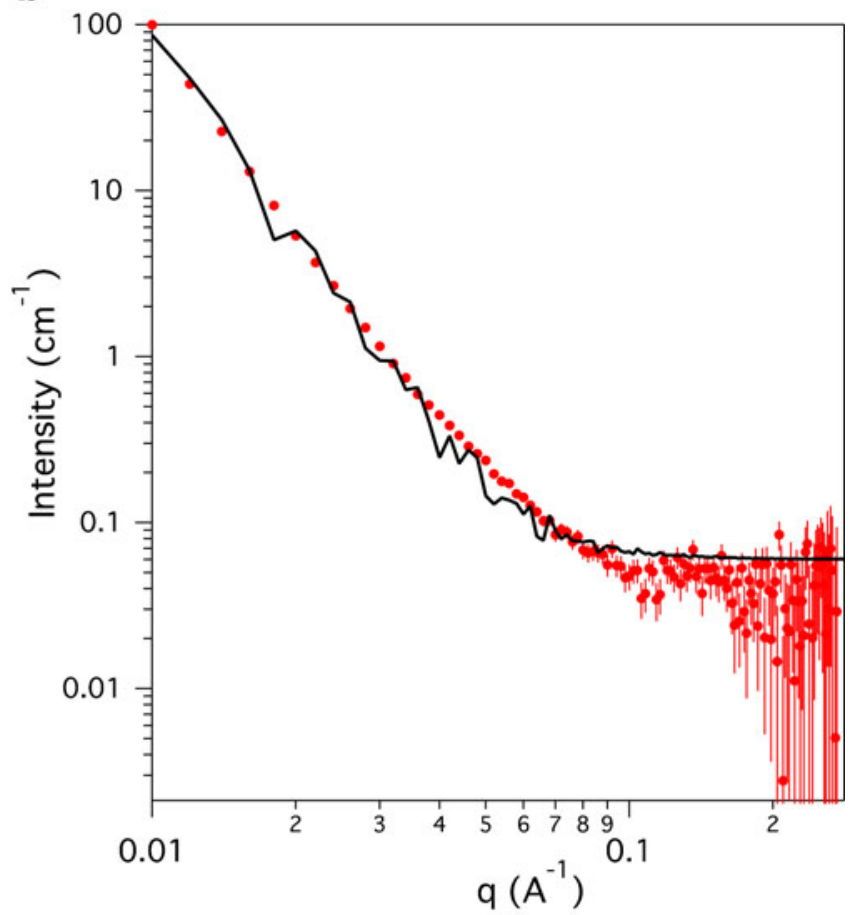

pattern consistent with an elliptical shape approximately two orders of magnitude smaller than the compartmentalised proteins in the purified OB preparation (red) 
preparation was no longer present (Fig. 1b). The $10 \%$ $\mathrm{D}_{2} \mathrm{O}$ sample suggests that the relative concentration of free protein has been reduced significantly with respect to the crude preparation, as there is no longer evidence for an elliptical protein after purification of the OBs (Fig. 1c). This was in agreement with the reduction in the amount of helianthinin and ribosomal proteins observed (GeLC-MS/ MS, see below). This suggested that the oil body

Table 1 Identities and relative amounts (optical density) of proteins present

\begin{tabular}{|c|c|c|c|c|c|c|c|}
\hline ID & Band & $\begin{array}{l}\text { Observed } \\
\text { mass }^{\mathrm{a}} \\
(\mathrm{kDa})\end{array}$ & $\begin{array}{l}\text { Matching peptides } \\
\text { found in MS/MS }\end{array}$ & $\begin{array}{l}\text { Database entry } \\
\text { number and } \\
\text { species }\end{array}$ & $\begin{array}{l}\text { Closest homologue } \\
\text { in Viridiplantae }\end{array}$ & $\begin{array}{l}\text { Optical } \\
\text { density }\end{array}$ & $\pm^{\mathrm{b}}$ \\
\hline Caleosin A & $\mathrm{F}$ & 28.1 & $\begin{array}{l}\text { VAFDPFGWTAAK } \\
\text { MEWAILYALAK } \\
\text { CFDGSLFDYCAK } \\
\text { TDLETHLPKPYLAR } \\
\text { TVPDKLTLGEIWNMTEGNR }\end{array}$ & $\begin{array}{l}\text { EL461280 } \\
\text { H. tuberosus }\end{array}$ & $\begin{array}{l}\text { Caleosin; Sesamum } \\
\text { indicum, gi| } \\
6478218\end{array}$ & $3.1 \%$ & $0.31 \%$ \\
\hline Caleosin B & G & 26.3 & $\begin{array}{l}\text { MEWAILYALAK } \\
\text { CFDGSLFDYCAK } \\
\text { YMPVHFENMFSK } \\
\text { TDLETHLPKPYLAR } \\
\text { GLVAPDTEHPNGTLGHR } \\
\text { TVPDKLTLGEIWNMTEGNR } \\
\text { VMAMADGNALTPEADCQPLTHER }\end{array}$ & $\begin{array}{l}\text { EL460587 } \\
\text { H. tuberosus }\end{array}$ & $\begin{array}{l}\text { Caleosin; } S \text {. } \\
\text { indicum, } \\
\text { gi|6478218 }\end{array}$ & $5.7 \%$ & $0.54 \%$ \\
\hline $\begin{array}{l}\text { Hydrosteroid 11- } \\
\beta \text {-dehydrogenase } \\
\text { A (steroleosin A) }\end{array}$ & $\begin{array}{l}\mathrm{A}, \mathrm{B} \\
\mathrm{D} \\
\mathrm{E}\end{array}$ & $\begin{array}{l}45(\times 2) \\
\quad 36.2,33.4\end{array}$ & $\begin{array}{l}\text { AALAQFFETMR } \\
\text { MVDQTVHHFNR } \\
\text { IIALSSAASWIPLPR } \\
\text { ITLVTPGFIESELTQGK } \\
\text { VVLITGASSGIGEHIAYEYASR }\end{array}$ & $\begin{array}{l}\text { GE513976 } \\
\text { H. annuus }\end{array}$ & $\begin{array}{l}\text { Steroleosin; } S \text {. } \\
\quad \text { indicum, gi| } \\
16033752\end{array}$ & $9.2 \%$ & $1.95 \%$ \\
\hline $\begin{array}{l}\text { Hydrosteroid 11- } \\
\beta \text {-dehydrogenase } \\
\text { B (steroleosin B) }\end{array}$ & $\mathrm{C}$ & 38.2 & $\begin{array}{l}\text { AALVNFYETLR } \\
\text { FINETINYFGR } \\
\text { LLGAPDVLIMAADVVK } \\
\text { IVVNAAVENWLPLPR }\end{array}$ & $\begin{array}{l}\text { EL457176 } \\
\text { H. tuberosus }\end{array}$ & $\begin{array}{l}\text { Steroleosin-B; } S . \\
\text { indicum, gi| } \\
21311775\end{array}$ & $3.5 \%$ & $0.01 \%$ \\
\hline Oleosin A & $\mathrm{J}$ & 18.2 & $\begin{array}{l}\text { GGHYGTAGVHTGGPGGGVGTYV } \\
\text { YVTGEQPSGADTSDEASHR }\end{array}$ & $\begin{array}{l}\text { CD856507 } \\
\text { H. annuus }\end{array}$ & $\begin{array}{l}\text { Oleosin 1; Prunus } \\
\text { dulcis, gi|460803 }\end{array}$ & $19.1 \%$ & $3.62 \%$ \\
\hline Oleosin B & $\mathrm{M}^{\mathrm{c}}$ & 15.1 & $\begin{array}{l}\text { YDQQTHSQSTSR } \\
\text { QTAGSVPESLDYVK } \\
\text { IQSTAHEMGDQGQVGVHAQVGGGK } \\
\text { LQDLVEYTGQK } \\
\text { RLQDLVEYTGQK }\end{array}$ & $\begin{array}{l}\text { gi } \mid 266694 \\
\text { H. annuus }\end{array}$ & $\begin{array}{l}\text { Oleosin H-isoform; } \\
\text { Ficus pumila, (var. } \\
\text { Awkeotsang) gi| } \\
148283921\end{array}$ & $17.0 \%{ }^{\mathrm{c}}$ & $0.28 \%$ \\
\hline Oleosin C & $\mathrm{K}$ & 17.0 & $\begin{array}{l}\text { STMSVPDQMDYVK } \\
\text { LQDVGEYTGQK }\end{array}$ & $\begin{array}{l}\text { gi } \mid 1345520 \\
\text { H. annuus }\end{array}$ & $\begin{array}{l}\text { Oleosin } 18.2 \mathrm{KDa} \text {; } \\
\text { Gossypium } \\
\text { hirsutum, gi| } \\
167363\end{array}$ & $19.8 \%$ & $0.78 \%$ \\
\hline Oleosin D & $\mathrm{L}$ & 16.3 & $\begin{array}{l}\text { LQDLVEYTGQK } \\
\text { AHDIGPEGAVHAGSAVGGAK }\end{array}$ & $\begin{array}{l}\text { EL512172 } \\
\text { H. exilis }\end{array}$ & $\begin{array}{l}\text { Oleosin S1-2; Brassi } \\
\text { ca napus, gi| } \\
196122060\end{array}$ & $22.6 \%$ & $5.84 \%$ \\
\hline Oleosin E & $\mathrm{M}^{\mathrm{c}}$ & 15.1 & YATGGHPLGSDSLDQAR & $\begin{array}{r}\text { EL511252 } \\
\text { H. exilis }\end{array}$ & $\begin{array}{l}\text { Oleosin low- } \\
\text { molecular-weight } \\
\text { isoform; Linum usi } \\
\text { tatissimum, gi| } \\
77737584\end{array}$ & $17.0 \%{ }^{\mathrm{c}}$ & $0.28 \%$ \\
\hline Total & & & & & & $100.0 \%$ & \\
\hline
\end{tabular}

Gel shown in Supplementary Figure 1

${ }^{a}$ Measure estimated from migration on SDS-PAGE

${ }^{\mathrm{b}}$ Standard error

${ }^{\mathrm{c}}$ Band contained peptides for two distinct oleosins and thus the optical density quoted is for the combination of both isoforms 
preparation protocol was competent to isolate oil bodies with impurities below the level of detection. This was verified using GeLC-MS/MS.

\section{OB fractionation}

Only OBs isolated according to the procedure informed by SANS and SDS-PAGE followed by GeLC-MS/MS were used for the profiling data presented in this work. The OBs were isolated and then fractionated into the triglyceride (oil), lipid, and protein fractions for characterisation. The OBs were doped before drying with a known mass of lyso-PG as a quantitative lipid standard before fractionation and dried under reduced pressure. Triglycerides were extracted using petroleum spirit and the lipid fraction using a mixture of chloroform, ethanol and triethylamine (3:1:1, 'CET') developed for this application. Triethylamine was used in order to produce triethylammonium cations and thus facilitate dissolving of the most acidic lipid species in an organic solvent system. The remaining matter after these extractions contained the proteome. OB fractionation revealed that they comprised the following by mass: triglycerides $(98.63 \% \pm 0.01 \%)$, lipids $(0.31 \% \pm$ $0.039 \%)$ and protein $(1.06 \% \pm 0.001 \%)$.

Proteome: peptide separation, tandem MS and peptide identification

Proteins were separated by SDS-PAGE (Supplementary Figure 1) and enzymatically digested with trypsin to

a

b
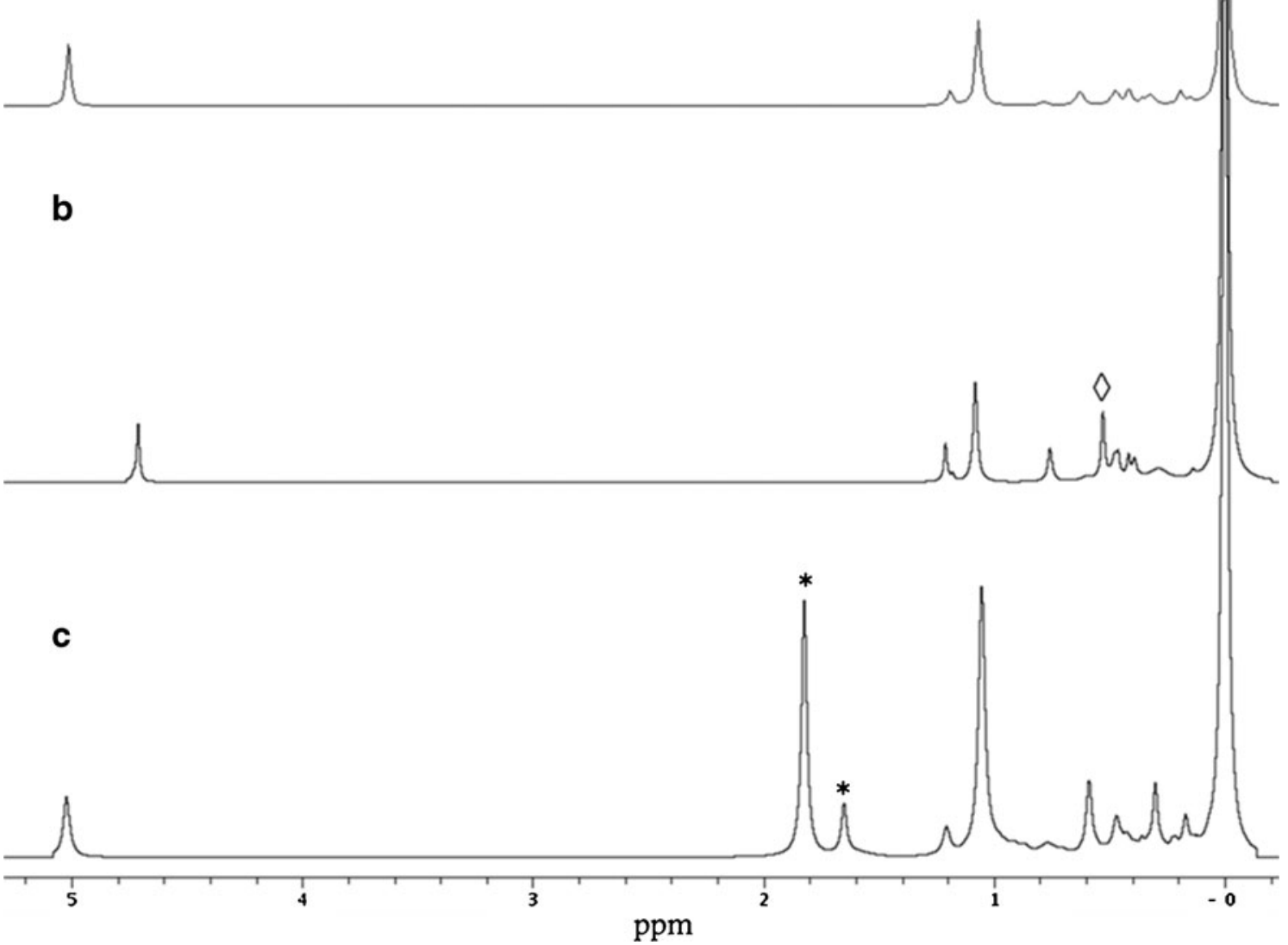

Fig. $2{ }^{31} \mathrm{P}$ NMR spectra of lipidomes of OBs from helianthus OBs. Trace A is a lipid isolate without added enzyme inhibitors. Trace B is from a lipidome isolation containing BPBA (non-selective PLA P $_{x}$ inhibitor) and $n$-butanol. The signal arising from PB is marked with an open diamond. Trace $\mathrm{C}$ is from a lipid fraction isolated with PLA $_{\mathrm{x}}$, PLC and
PLD inhibitors, and the quantitative standard (lyso-PG, signals arising from the $1-O$ and 2-O isomers are marked with an asterisk). There is some variation in the shift of the PA signal due to the formation of triethylammonium adducts with the solvent system and appears to be partly concentration-dependent with respect to the lipid 
peptides before LC-MS/MS and analysis. GeLC-MS/ MS revealed a proteome comprising three protein families, namely: oleosins, caleosins and steroleosins [28, $29,33,34,45,66,68]$. The relative quantities of proteins observed were measured using densitometry of colloidal Coomassie-stained SDS-PAGE gels $(n=3)$ (Table 1), indicating that oleosins (bands K-M, types A-E) account for around $78 \%$ of the proteome by mass, whereas steroleosins account for around $13 \%$ and caleosins for around $9 \%$. When present, traces of extraneous proteins were observed as a discrete band with a low staining intensity (helianthinin isoforms, band H, Supplementary Figure 1).

Lipidome: lipase activity

Isolation of the lipid fraction from de-hulled Helianthus seeds in a simple buffered medium showed a surprisingly narrow range of lipid head groups, with only phosphatidylcholine (PC), phosphatidylinositol (PI) and phosphatidic acid (PA) visible (Fig. 2). This is at odds with the compelling evidence that a significantly richer diversity of lipid head groups is present in the few biological systems for which comprehensive lipidomics data currently are available $[17,22,54]$. This led us to hypothesise that lipase activity was affecting the observed lipid profile. The use of the non-selective phospholipase A 1 and 2 (collectively known as $\mathrm{PLA}_{\mathrm{x}} \mathrm{s}$ ) inhibitor BPBA succeeded in increasing and making consistent the isolated mass of the lipidome. Although this strongly suggested that $\operatorname{PLA}_{x} \mathrm{~s}$ were indeed present, no further head group types were observed. We therefore examined the possibility that other lipases were active in the system.
The presence of PA alerted us to the possible activity of phospholipase D (PLD). PLDs are known to hydrolyse several lipid head groups, invariably producing phosphatidic acid [4, 48, 53]; however, $n$-butanol has been shown to suppress the formation of PA, with evidence that phosphatidylbutanol (PB, structure shown in Supplementary Figure 20) is produced instead [32, 51]. This has been reported to occur at concentrations of $n$-butanol as low as $0.01 \%, v / v[8,41,57]$. Thus the presence of PB provides a useful molecular marker for PLD activity. The possible activity of PLDs was therefore tested with a qualitative PLD assay comprising $n$-butanol.

\section{Lipidome: PLD assay}

The change in lipidome according to lipid head group profile in this assay was tracked through the change in lipid profile of ground $H$. annuus cotyledons suspended in buffered aqueous medium in the presence of $n$-butanol, agitated at $4{ }^{\circ} \mathrm{C}$ over a period of days (Fig. 3). The lipid profiles at given time points $(24,48,72 \mathrm{~h}, 9$ days) were determined by ${ }^{31} \mathrm{P}$ NMR. The appearance and dominance of a signal at $0.34 \mathrm{ppm}\left({ }^{31} \mathrm{P}\right.$ NMR$)$ was taken as a strong indication of the presence of a phosphorus-containing lipid that was not found in the lipid composition of commercially available lecithins already reported [6, 13, 14, 42], or in the mixture of lipids from Glycine max used in this project (Supplementary Figure 4), or from lipid species not previously identified in commercially available lipid mixtures (lyso-PS, PI-4-P, lysoPG; see Supplementary Figures 5-7, respectively, and Table 2 for ${ }^{31} \mathrm{P}$ NMR shifts). The presence of PB was confirmed by both mass spectrometry and ${ }^{31} \mathrm{P}$ NMR from samples of the lipid fraction isolated from OBs subject to 9 days' agitation,
Fig. $3{ }^{31} \mathrm{P}$ NMR PLD assay with time points shown. $\mathrm{PB}$ remains the dominant species throughout, though the integrations of the signals suggest that the majority of the $\mathrm{PB}$ is produced in the first $24 \mathrm{~h}$. The reduction in fraction of all other lipids (especially PA, PC and PI shown here) suggests that PLD acts on a variety of substrates, and/or that other lipases are present

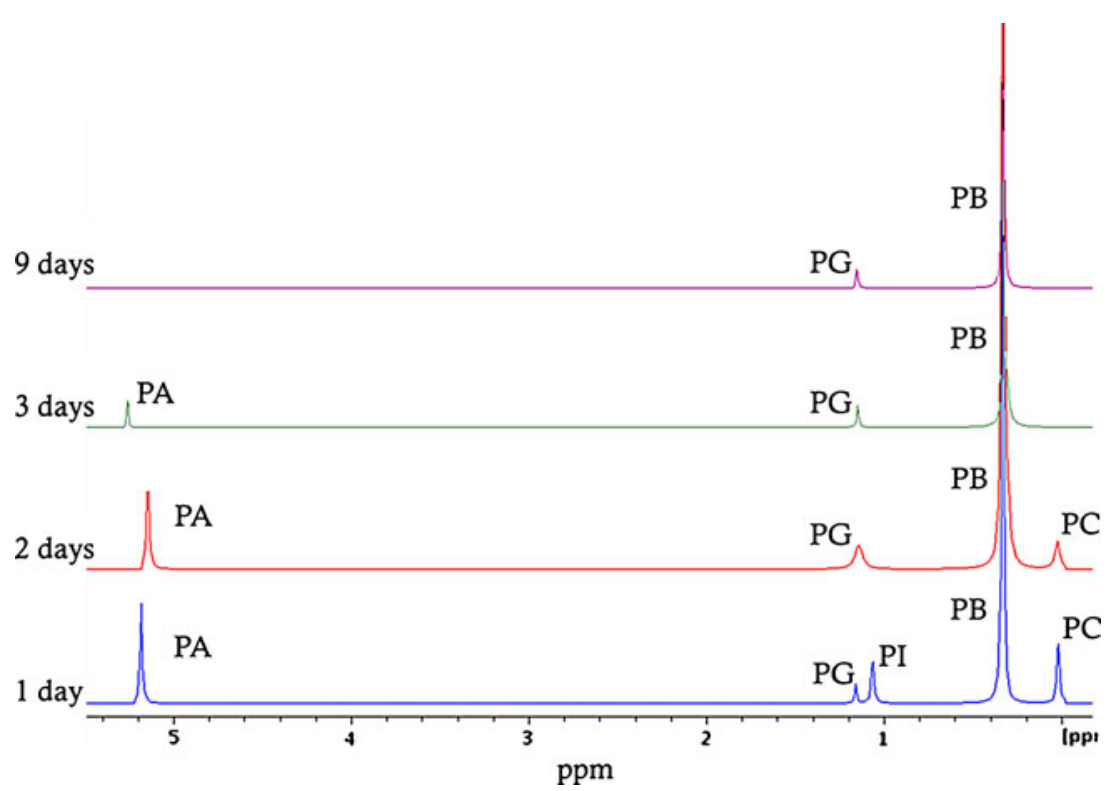


i.e. where the new $(\mathrm{PB})$ resonance dominated most strongly over other lipid species (Fig. 3). The presence of the resonance at $0.34 \mathrm{ppm}$ in isolated lipidomes, attributed to $\mathrm{PB}$, was therefore taken as evidence of PLD activity.

Lipase activity in this system cannot be attributed to microbial activity, as no evidence of either spore-forming or Pseudomonas species could be found. We ascribe this apparent sterility to a combination of the bactericidal $n$-butanol concentration, to the bacteriostatic temperature of the assay $\left(\leq 4{ }^{\circ} \mathrm{C}\right)$, and to the bacteriostatic PLA $\mathrm{x}_{\mathrm{x}}$ inhibitor.
We noted that the suppression of PLA activity and the redirection of PLD activity to give PB instead of PA (with $n$ butanol) allowed the activity of phospholipase Cs (PLCs) to be observed qualitatively. A peak in PB concentration after around $48 \mathrm{~h}$ suggests that it too is being consumed in this system. Bacterial activity may be ruled out (see above), as is a change in lipid profile by destruction of the organelles; they remain intact as no release of triglycerides was observed. The reduction in total PB cannot be ascribed to PLD activity without the formation of PA, which is not observed. Thus,
Table 2 Lipidome of OBs from H. annuиs

Quantitative standard lyso-PG, $n=3$. $\mathrm{U}_{1-8}$ represents the resonances of lipids that are at present unknown. There was no evidence for the formation of the biomarker PB in the samples used to compile this data.

Fatty acids: 24:0 lignoceric acid, 22:0 behenic acid, 18:3 $\alpha$ linolenic acid, 18:2 linoleic acid, 18:1 oleic acid, 18:0 stearic acid, 16:0 palmitic acid.

${ }^{\text {a }}$ Resonances for which the shifts are consistent with known lipid species $\left(\mathrm{U}_{6}, \mathrm{DMPE} ; \mathrm{U}_{8}, \mathrm{PC}\right.$ plasmalogen) but for which no appropriate ion fragments were observed in MS

${ }^{\mathrm{b}}$ Fatty acid profile consistent with mass given in parentheses, identified by MSn.

\begin{tabular}{|c|c|c|c|c|}
\hline Lipid & Fraction (mol., $n=3$ ) & \pm & ${ }^{31} \mathrm{P}$ NMR shift (ppm) & Ion mass (es) ${ }^{b}$ \\
\hline PA & $3.00 \%$ & $0.81 \%$ & $4.82-5.10$ & $\begin{array}{l}699.5 \text { (C18:2/C18:0, C18:1/C18:1) } \\
671.5(\mathrm{C} 16: 0 / \mathrm{C} 18: 2) \\
673.5(\mathrm{C} 16: 0 / \mathrm{C} 18: 1) \\
695.5(\mathrm{C} 18: 2 / \mathrm{C} 18: 2) \\
697.5(\mathrm{C} 18: 2 / \mathrm{C} 18: 1)\end{array}$ \\
\hline lyso-PG & $0.04 \%$ & $0.01 \%$ & 1.72 & $509(\mathrm{C} 18: 1 / 0: 0)$ \\
\hline lyso-PI & $0.72 \%$ & $0.65 \%$ & 1.53 & $571.5(\mathrm{C} 16: 0 / 0: 0)$ \\
\hline lyso-PE & $0.24 \%$ & $0.13 \%$ & 1.23 & $\begin{array}{l}452(\mathrm{C} 16: 2 / 0: 0) \\
476(\mathrm{C} 18: 2 / 0: 0)\end{array}$ \\
\hline PG & $1.81 \%$ & $0.33 \%$ & 1.21 & $\begin{array}{l}745.5 \text { (C18:2/C16:0) } \\
769.5 \text { (C18:2/C18:2) } \\
771.5 \text { (C18:2/C18:1) } \\
773.5 \text { (C18:0/C18:2) }\end{array}$ \\
\hline PI & $19.97 \%$ & $2.18 \%$ & 1.02 & $\begin{array}{l}833.5 \text { (C18:2/C16:0) } \\
857.5 \text { (C18:2/C18:2) } \\
861.5 \text { (C18:2/C18:0) } \\
917 \text { (C18:2/C22:0) }\end{array}$ \\
\hline $\mathrm{U}_{1}$ & $0.73 \%$ & $1.09 \%$ & 0.77 & - \\
\hline PE & $4.04 \%$ & $0.42 \%$ & $0.65-0.58$ & $\begin{array}{l}714.5(\mathrm{C} 18: 2 / \mathrm{C} 16: 0) \\
716.5(\mathrm{C} 16: 0 / \mathrm{C} 18: 1) \\
738.5(\mathrm{C} 18: 2 / \mathrm{C} 18: 2) \\
742(\mathrm{C} 18: 3 / \mathrm{C} 18: 0) \\
826.5(\mathrm{C} 18: 2 / \mathrm{C} 24: 0)\end{array}$ \\
\hline PS & $0.77 \%$ & $0.96 \%$ & 0.52 & - \\
\hline lyso-PC & $2.38 \%$ & $0.47 \%$ & $0.45-0.49$ & $\begin{array}{l}496.5(\mathrm{C} 16: 0 / 0: 0) \\
520.5(\mathrm{C} 18: 2 / 0: 0)\end{array}$ \\
\hline $\mathrm{U}_{2}$ & $1.14 \%$ & $0.32 \%$ & 0.42 & - \\
\hline $\mathrm{U}_{3}$ & $0.34 \%$ & $0.60 \%$ & 0.38 & - \\
\hline $\mathrm{U}_{4}$ & $1.14 \%$ & $1.10 \%$ & 0.36 & - \\
\hline $\mathrm{U}_{5}$ & $2.57 \%$ & $1.53 \%$ & 0.30 & - \\
\hline $\mathrm{U}_{6}{ }^{\mathrm{a}}$ & $0.57 \%$ & $0.31 \%$ & $0.28-0.25$ & - \\
\hline $\mathrm{U}_{7}$ & $1.00 \%$ & $0.26 \%$ & 0.24 & - \\
\hline $\mathrm{U}_{8}{ }^{\mathrm{a}}$ & $1.22 \%$ & $0.81 \%$ & 0.17 & - \\
\hline $\mathrm{PC}$ & $58.59 \%$ & $4.08 \%$ & 0.00 & $\begin{array}{l}782.5 \text { (C18:2/C18:2) } \\
784.5 \text { (C18:2/C18:1) } \\
758.5 \text { (C18:1/C16:0) } \\
733.5 \text { (C16:0/C16:0) }\end{array}$ \\
\hline Total & $100.00 \%$ & & & \\
\hline
\end{tabular}


we suspected that the hydrolysis of PB hinted at the activity of one or more phospholipase $\mathrm{C}$ isoforms (PLCs) on this lipid species. PLCs are known to hydrolyse inositides (PI is also hydrolyzed in this system) and with some evidence for hydrolysis of PC [49, 51] (also hydrolyzed in this assay). PLC activity on lipids gives rise to DAGs and releases the (hydrophilic) head group in the aqueous medium, reducing the total amount of phosphorus in the lipid fraction. Thus, in order to determine the lipidome of this organelle, we used comprehensive lipase inhibition designed to suppress PLA ${ }_{x}$, PLC and PLD activity.

Lipidome isolation The evident necessity of suppressing PLA $_{\mathrm{x}}$, PLC and PLD activities in order to isolate a lipidome with confidence led us to use a cocktail of known, commercially available, lipase inhibitors $[5,21,57,64$, 65] (see "Experimental section"). No resonance in the NMR spectra or MS ions/fragments associated with $\mathrm{PB}$ was observed in lipidomes isolated under conditions including comprehensive lipase inhibition, despite the presence of $n$ butanol. Signals at 0.36 and 0.31 ppm (Fig. 4a) can be ruled out as indicators of $\mathrm{PB}$, as a combination of ${ }^{31} \mathrm{P} \mathrm{HSQC},{ }^{13} \mathrm{C}$ HSQC, ${ }^{13} \mathrm{C}$ HMBC and TOCSY spectra have allowed us to identify $\mathrm{PB}$ resonances unambiguously (Figure $4 \mathrm{~b}$, assignment list in Supplementary Information). This has allowed us to demonstrate that the connectivity of the species identified is consistent with PB (Supplementary Figure 20). As this work has identified a number of characteristic resonances in this biomarker, this approach to identifying phosphoruscontaining species has the scope for demonstrating the
Fig. 4 a ${ }^{31} \mathrm{P}$ NMR showing the comparison of lipidome samples containing PB (unbroken line, unstarred labels) and not containing it (dashed line, starred labels); $\mathbf{b}$ ${ }^{1} \mathrm{H},{ }^{1} \mathrm{H}$ TOCSY showing through bond coupling identifying glyceryl-sn-1-3 (panel, left) and butyl (B1-B4) protons (panel, right).

Projections shown opposite the $x$ and $y$ axes indicate protons coupled to ${ }^{31} \mathrm{P}$ and are taken from a slice through a ${ }^{31} \mathrm{P},{ }^{1} \mathrm{H}$ HSQC experiment at the ${ }^{31} \mathrm{P}$ chemical shift of $0.34 \mathrm{ppm}$ (characteristic of $\mathrm{PB}$ in a $1 \mathrm{D}^{31} \mathrm{P}$ experiments, (a)). The subscript notations used above are the same as the notations in Supplementary Figure 20

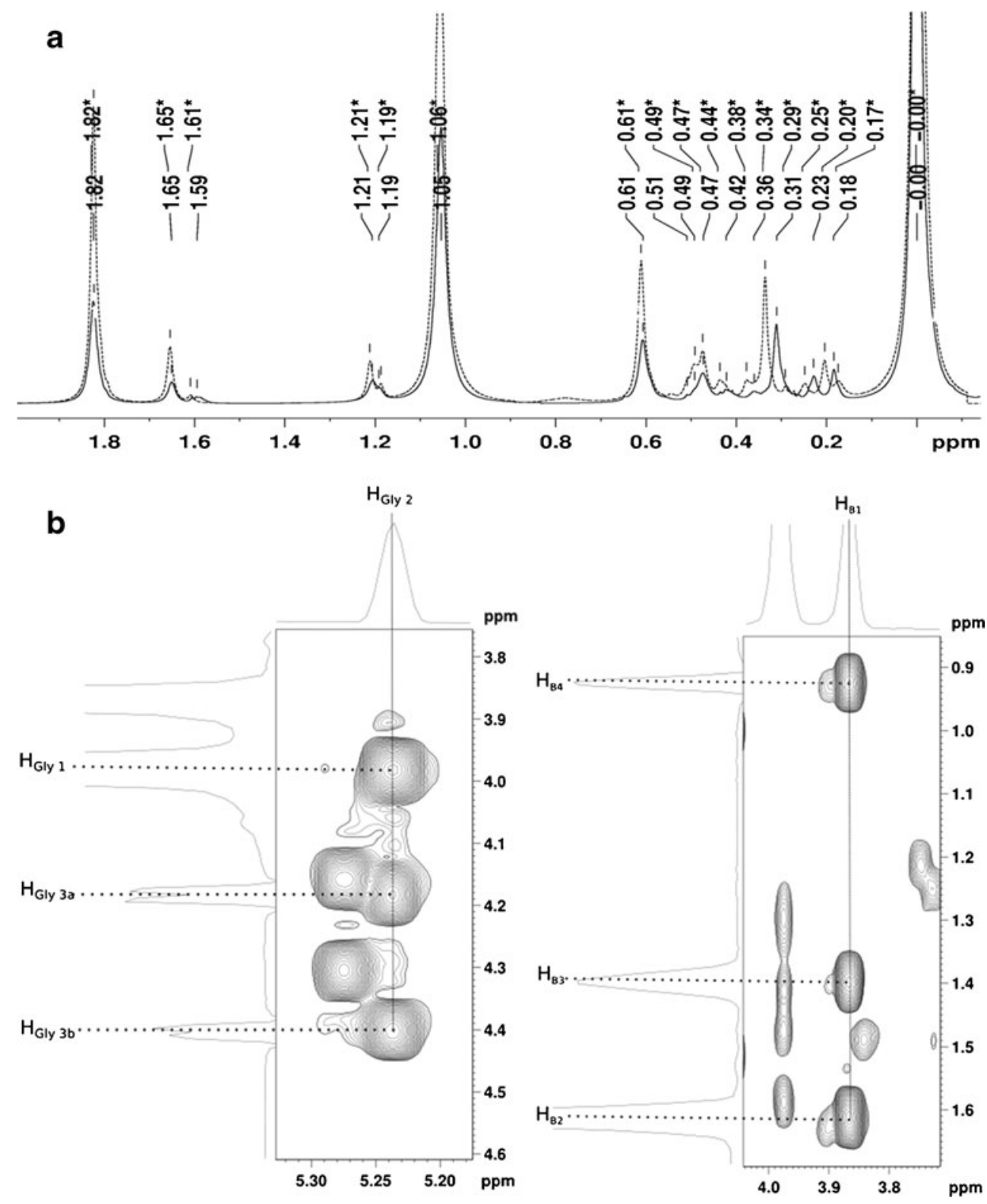


presence of $\mathrm{PB}$ in complicated mixtures of phosphoruscontaining molecules, even where $\mathrm{PB}$ is a minor component.
The inclusion of PLC inhibitors D609 and U73122 in grinding media indicated measurable changes to the PI and

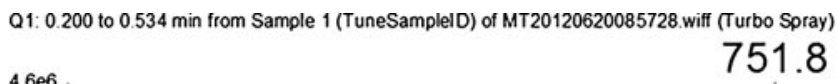

Max. $4.6 \mathrm{e} 6$

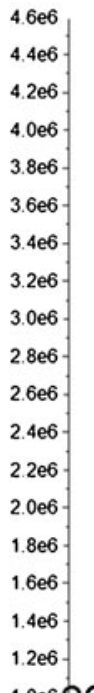

1.006235 .2

$8.0 \mathrm{e} 5-$

$6.0 \mathrm{e} 5$.

$4.0 \mathrm{e} 5$

$2.0 \mathrm{e} 5$

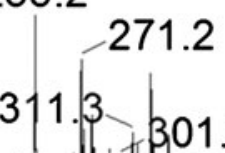

\section{4}

727.8

Accurate mass m/z 751.5293

and 727.5287

200

300

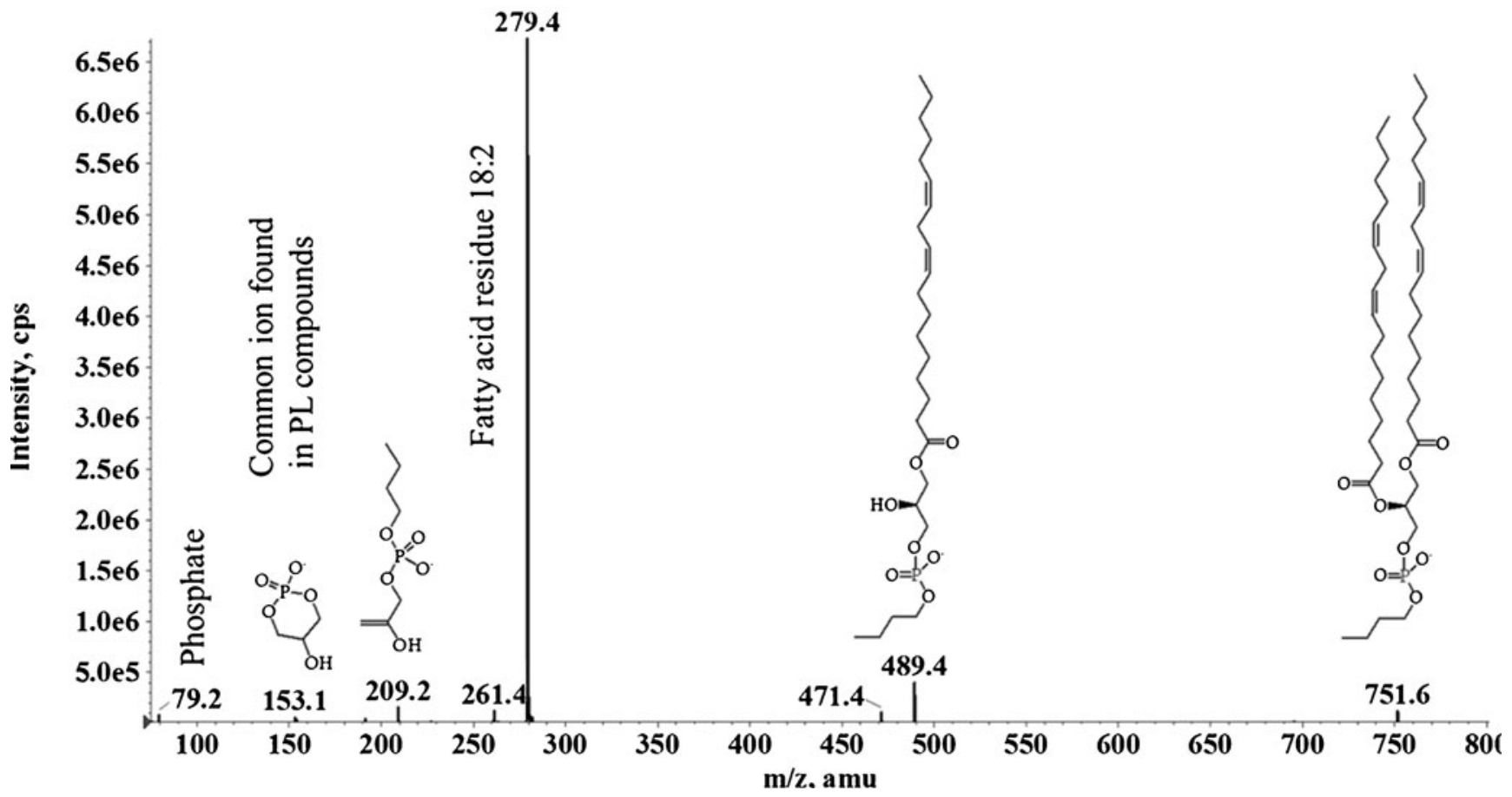

Fig. 5 Mass spectrum of PB (from PLD assay). $m / z \quad 751-5,293=$ dilinoleoylphosphatitdylbutanol, $m / z \quad 727-5,287=$ palmitoyllinoleoylphosphatidylbutanol 
PC fractions (viz. traces 2 and 3, Fig. 2), supporting the hypothesis of activity consistent with members of the PLC family.

The lipidome of the $\mathrm{OB}$ of mature $H$. annuus seeds is presented in Table 2. In order to overcome the inherent variation in biological systems, we repeated the isolation $(n=3)$, using a quantitative phosphorus (lipid) standard. The lipidomes isolated without a quantitative standard show that the presence of lyso-phosphatidylglycerol (lyso-PG) is $0.04 \%$ $( \pm 0.01 \%)$, and analysis of this lipid species in vitro shows that the shift of its resonances (1.82 and $1.64 \mathrm{ppm}$, for the 1-Oand 2- $O$-fatty acid derivatives, respectively) are conveniently distant from the resonances arising from other species, to make quantification reliable. The head group identification has been made both in NMR spectra and in MS traces; however, ${ }^{31} \mathrm{P}$ NMR suggest the presence of traces of lipids that have not yet been identified $\left(\mathrm{U}_{1-8}\right)$. Unfortunately, it was not possible to use MS signals from spectra of the lipidomes (Supplementary Figure 9) to inform this further.

Fatty acid fraction

Strikingly, the fatty acid fraction from lipidome samples ( ${ }^{1} \mathrm{H}$ NMR) was remarkably simple; the mixture it comprises is dominated by palmitic, linoleic and oleic acids (2:1:0.25, respectively, ${ }^{1} \mathrm{H}$ NMR of hydrolytic products, Supplementary Figures 2 and 3 ). This select group of fatty acids is also observed in the fragmentation of PB under electrospray ionisation (Fig. 5). These data support the hypothesis that the PB is formed not only from the bulk of the lipid present in what appears to be a non-selective manner; it is in agreement with the fatty acid fragmentation of the principle lipid components of the lipidome, PC (Supplementary Figures 10 and 11), PA (Supplementary Figure 12), PG (Supplementary Figure 13), PI (Supplementary Figure 14) and PE (Supplementary Figure 15). This suggests that, although there is some richness in the head group profile of the lipid fraction of the OB, a wide variety of fatty acid residues is not useful to the organism and may even be undesirable.

Lipidome: oil The principle component of an OB in terms of mass is undoubtedly its triglyceride fraction [29, 66, 69]. In the OBs examined in the present study, this fraction represented $98.63 \% \pm 0.01 \%$ of the mass of the organelle (see above). The triglycerides were characterised in this study using NMR (Supplementary Figure 8) and MS (Supplementary Figure 16-19). ${ }^{1} \mathrm{H}$ NMR indicates that there is an average of 1.5 olefin bonds per fatty acid residue (Supplementary Figure 8). MS suggests that, within this average, there is a mixture of triglycerides with $0,2,3$ and 4 double bonds, with evidence for an abundant triglyceride species containing only linoleoyl residues (two olefin bonds, Supplementary Figure 17). There is evidence for the presence of trace amounts of dihomo- $\gamma$-linolenic (20:3) and 7,10,13,16-docosatetraenoic (22:4) acid residues (Supplementary Figure 16).

\section{Discussion}

The results of this study indicate that the lipidome of OBs from $H$. annuus (common sunflower) is much broader than previously expected $[66,67]$. Additionally, the use of smallmolecule lipase inhibitors is crucial in determining the composition of that lipid fraction accurately. This work also shows that the protein fraction is larger in mass than the lipid fraction by a factor of 23.4 , suggesting an important structural role for the proteins.

A comparison of the molecular profile of Helianthus OBs with recent physical evidence also suggests an important structural influence of the protein fraction. Recent physical evidence indicates that the lipid fraction in isolation would be likely to exhibit a different surface curvature to that of naturally occurring OBs. Mixtures of PC and PI (4:1) have been shown to produce surfaces that curve towards the cytosol [40] rather than away from it, as in the OB surface. This suggests that another component of the OBs' surface, not found in the lipid fraction, is able to direct the topology of the surface of this organelle. The evidence from this work shows that a protein fraction containing amphiphilic proteins is a large and integral part of the monolayer that makes forms the surface. Importantly, the proteome of this organelle is dominated by oleosin isoforms ( $78 \%$ by densitometry, Supplementary Figure 1 ).

The hypothesis that the physical properties of the proteins dominate that of the surface is supported by the observation that OBs stay intact when the relatively rich lipidome found

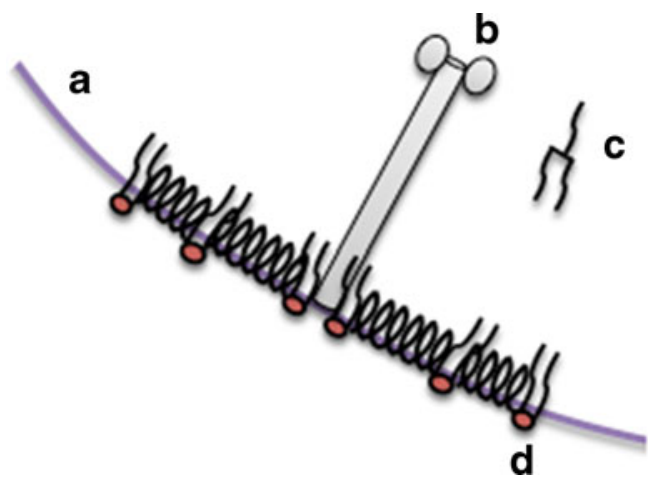

Fig. 6 Schematic diagram of the OB, given the composition described above, and known thermodynamic behaviour $[29,61]$ of amphiphilic proteins, lipids and triglycerides. A Neutral surface [61] of the monolayer of the $\mathrm{OB}$; $\mathbf{b}$ oleosin; $\mathbf{c}$, triglyceride matrix (one molecule shown for clarity); d, phospholipid. Scale: the lipid molecules (d) are 1.8$2.0 \mathrm{~nm}$ long [12], and the oleosin helix that extends into the triglyceride matrix is $12 \mathrm{~nm}$ long [29]. NB the length of the lipid molecules represents around $0.1 \%$ of the width of the organelle itself 
in vivo is converted into a lipid fraction that is dominated by PB $\left(>90 \%,{ }^{31} \mathrm{P}\right.$ NMR). This strongly suggests that the lipid fraction of the surface does not dominate the physical properties of the $\mathrm{OB}$ structure under the hydrating conditions used in this study. It is clear from physical studies that a surface composed entirely of any combination of known biological lipids would be unable to sustain the surface topology of OBs through these changes in hydration [40, $60,61,63]$. The oleosin-rich proteome, whatever the biological function of the individual proteins, therefore seems to be an important player in maintaining the remarkable physical stability of this organelle. Not only are the proteins amphiphilic [44, 69], but this evidence suggests that they also have an implicit thermodynamic role in maintaining the integrity of the organelle, alongside the lipid fraction, as part of its monolayer surface.

We suggest that the evidence presented here supports an updating of the current model for the assembled structure of naturally occurring OBs, a fragment of which is shown schematically in Fig. 6.

In summary, the evidence from this study about the molecular profile of OBs from $H$. annuus shows a monolayer dominated by proteins in terms of mass and perhaps also in terms of its physical properties. The molecular profile generated can be used not only to inform our understanding of the physical properties of this organelle but also its metabolism and general behaviour in vivo. This can also be applied to the preparation of synthetic OBs in applications such as biotechnological engineering (e.g. adjuvants for vaccines and recombinant therapeutics) and in the food industry (e.g. preparing emulsions and controlling flavour). The chemical techniques used have enabled us to identify a range of species in the proteome and lipidome, as well as some that may not have been observed to date.

Acknowledgements The authors would like to thank the Department for the Environment, Farming and Rural Affairs (DEFRA) and the LINK scheme for funding (Sustainable Emulsions through Bioinnovation Project) for funding this work. The authors would like to thank Prof. Christine Dodd and Dr. Philip Richards for assistance with microbiological assessment, Dr. Adrienne Davis and Mr. Kevin Butler for assistance with NMR and Dr. Kenneth Davis for assistance with protein densitometry. The authors would like to thank Drs. G. Campbell, C. B. Harvey and N. Wenta for helpful discussions.

Funding sources The authors would like to thank the Department for the Environment, Farming and Rural Affairs (DEFRA) and the LINK scheme for funding (Sustainable Emulsions through Bioinnovation Project) for funding this work.

\section{References}

1. Alley SH, Ces O, Templer RH, Barahona M (2008) Biophysical regulation of lipid biosynthesis in the plasma membrane. Biophys $\mathrm{J}$ 94(8):2938-2954. doi:10.1529/biophysj.107.118380
2. Bain JR, Stevens RD, Wenner BR, Ilkayeva O, Muoio DM, Newgard CB (2009) Metabolomics applied to diabetes research. Diabetes 58 (11):2429-2443. doi:10.2337/db09-0580

3. Bhatla SC, Kaushik V, Yadav MK (2010) Use of oil bodies and oleosins in recombinant protein production and other biotechnological applications. Biotechnol Adv 28(3):293-300. doi:10.1016/ j.biotechadv.2010.01.001

4. Billah MM, Pai JK, Mullmann TJ, Egan RW, Siegel MI (1989) Regulation of phospholipase D in HL-60 granulocytes. Activation by phorbol esters, diglyceride, and calcium ionophore via protein kinase-independent mechanisms. J Biol Chem 264(15):9069-9076

5. Bleasdale JE, Thakur NR, Gremban RS, Bundy GL, Fitzpatrick FA, Smith RJ, Bunting S (1990) Selective inhibition of receptorcoupled phospholipase C-dependent processes in human platelets and polymorphonuclear neutrophils. J Pharmacol Exp Ther 255 (2):756-768

6. Bosco M, Culeddu N, Toffanin R, Pollesello P (1997) Organic solvent systems for P-31 nuclear magnetic resonance analysis of lecithin phospholipids: applications to two-dimensional gradientenhanced $\mathrm{H}$-1-detected heteronuclear multiple quantum coherence experiments. Anal Biochem 245(1):38-47. doi:10.1006/ abio.1996.9907

7. Capuano F, Bond NJ, Gatto L, Beaudoin F, Napier JA, Benvenuto E, Lilley KS, Baschieri S (2011) LC-MS/MS methods for absolute quantification and identification of proteins associated with chimeric plant oil bodies. Anal Chem 83:9267-9272. doi:10.1021/ ac201733m

8. Chen YG, Siddhanta A, Austin CD, Hammond SM, Sung TC, Frohman MA, Morris AJ, Shields D (1997) Phospholipase D stimulates release of nascent secretory vesicles from the transGolgi network. J Cell Biol 138(3):495-504. doi:10.1083/ jcb.138.3.495

9. Chiang C-J, Chen CY-P, Tzen JTC (2005) Efficient system of artificial oil bodies for functional expression and purification of recombinant nattokinase in Escherichia coli. J Agric Food Chem 53(12):4799-4804. doi:10.1021/jf050264a

10. Clutterbuck AL, Smith JR, Allaway D, Harris P, Liddell S, Mobasheri A (2011) High throughput proteomic analysis of the secretome in an explant model of articular cartilage inflammation. J Proteome 74 (5):704-715. doi:10.1016/j.jprot.2011.02.017

11. Corsi J, Hawtin RW, Ces O, Attard GS, Khalid S (2010) DNA lipoplexes: formation of the inverse hexagonal phase observed by coarse-grained molecular dynamics simulation. Langmuir 26 (14):12119-12125. doi:10.1021/la101448m

12. Costigan SC, Booth PJ, Templer RH (2000) Estimations of lipid bilayer geometry in fluid lamellar phases. Biochim Biophys Acta (BBA)-Biomembranes 1468(1-2):41-54

13. Cremonini MA, Laghi L, Placucci G (2004) Investigation of commercial lecithin by P-31 NMR in a ternary CUBO solvent. J Sci Food Agric 84(8):786-790. doi:10.1002/jsfa.1683

14. Culeddu N, Bosco M, Toffanin R, Pollesello P (1998) P-31 NMR analysis of phospholipids in crude extracts from different sources: improved efficiency of the solvent system. Magn Reson Chem 36 (12):907-912. doi:10.1002/(sici)1097-458x(199812)36:12<907:: aid-omr394>3.0.co;2-5

15. Deckers H, Van Rooijen G, Boothe J, Goll J, Moloney M, Schryvers A, Alcantara J, Hutchins W (2004) Immunogenic formulations comprising oil bodies. United States Patent

16. Dennis EA (2009) Lipidomics joins the omics evolution. Proc Natl Acad Sci 106(7):2089-2090. doi:10.1073/pnas.0812636106

17. Dennis EA, Deems RA, Harkewicz R, Quehenberger O, Brown HA, Milne SB, Myers DS, Glass CK, Hardiman G, Reichart D, Merrill AH, Sullards MC, Wang E, Murphy RC, Raetz CRH, Garrett TA, Guan Z, Ryan AC, Russell DW, McDonald JG, Thompson BM, Shaw WA, Sud M, Zhao Y, Gupta S, Maurya 
MR, Fahy E, Subramaniam S (2010) A mouse macrophage lipidome. J Biol Chem 285(51):39976-39985. doi:10.1074/ jbc.M110.182915

18. Di Paolo G, De Camilli P (2006) Phosphoinositides in cell regulation and membrane dynamics. Nature 443(7112):651-657

19. Dubey JP, Liddell S, Mattson D, Speer CA, Howe DK, Jenkins MC (2001) Characterization of the Oregon isolate of Neospora hughesi from a horse. J Parasitol 87(2):345-353. doi:10.1645/ 0022-3395(2001)087[0345:cotoio]2.0.co;2

20. Ebbinghaus S, Kim SJ, Heyden M, Yu X, Gruebele M, Leitner DM, Havenith M (2008) Protein sequence- and $\mathrm{pH}$-dependent hydration probed by terahertz spectroscopy. J Am Chem Soc 130 (8):2374-2375. doi:10.1021/ja0746520

21. Ebdrup S, Jacobsen P, Farrington AD, Vedsø P (2005) Structureactivity relationship for aryl and heteroaryl boronic acid inhibitors of hormone-sensitive lipase. Bioorg Med Chem 13(6):2305-2312. doi:10.1016/j.bmc.2004.12.042

22. Ejsing CS, Sampaio JL, Surendranath V, Duchoslav E, Ekroos K, Klemm RW, Simons K, Shevchenko A (2009) Global analysis of the yeast lipidome by quantitative shotgun mass spectrometry. Proc Natl Acad Sci 106:2136-2141. doi:10.1073/ pnas.0811700106

23. Fisk I, Linforth R, Taylor A, Gray D (2011) Aroma encapsulation and aroma delivery by oil body suspensions derived from sunflower seeds $(<\mathrm{i}>$ Helianthus annuus $</ \mathrm{i}>)$. Eur Food Res Technol 232 (5):905-910. doi:10.1007/s00217-011-1459-z

24. Fisk ID, White DA, Lad M, Gray DA (2008) Oxidative stability of sunflower oil bodies. Eur J Lipid Sci Technol 110(10):962-968. doi:10.1002/ejlt.200800051

25. Frandsen GI, Mundy J, Tzen JTC (2001) Oil bodies and their associated proteins, oleosin and caleosin. Physiol Plant 112 (3):301-307. doi:10.1034/j.1399-3054.2001.1120301.x

26. Furse S, Tate EW, Woscholski R, Templer RH, Gaffney PRJ, Ces O (2012) Lipid membrane curvature induced by distearoyl phosphatidylinositol 4-phosphate. Soft Matter 8:3090-3093. doi: $10.1039 / \mathrm{c} 2 \mathrm{sm} 07358 \mathrm{~g}$

27. Hill DE, Liddell S, Jenkins MC, Dubey JP (2001) Detection of Neospora caninum oocysts in fecal samples from experimentallyinfected dogs using the polymerase chain reaction. J Parasitol 87 (2):395-398. doi:10.1645/0022-3395(2001)087[0395:sdonco] 2.0.co; 2

28. Huang AHC (1992) Oil bodies and oleosins in seeds. Annu Rev Plant Phys 43:177-200

29. Huang AHC (1994) Structure of plant seed oil bodies. Curr Opin Struc Biol 4(4):493-498

30. Jolivet P, Boulard C, Bellamy A, Larré C, Barre M, Rogniaux H, d'Andréa S, Chardot T, Nesi N (2009) Protein composition of oil bodies from mature Brassica napus seeds. Proteomics 9(12):3268 3284. doi:10.1002/pmic.200800449

31. Jolivet P, Roux E, Andrea S, Davanture M, Negroni L, Zivy M, Chardot T (2004) Protein composition of oil bodies in Arabidopsis thaliana ecotype WS. Plant Physiol Biochem 42(6):501-509. doi:10.1016/j.plaphy.2004.04.006

32. Kravets VS, Kolesnikov YS, Kretynin SV, Getman IA, Romanov GA (2010) Rapid activation of specific phospholipase(s) D by cytokinin in Amaranthus assay system. Physiol Plant 138 (3):249-255. doi:10.1111/j.1399-3054.2009.01324.x

33. Lin LJ, Tai SSK, Peng CC, Tzen JTC (2002) Steroleosin, a sterolbinding dehydrogenase in seed oil bodies (vol 128, pg 1200, 2002). Plant Physiol 129(4):1930-1930

34. Lin LJ, Tzen JTC (2004) Two distinct steroleosins are present in seed oil bodies. Plant Physiol Biochem 42(7-8):601-608. doi:10.1016/j.plaphy.2004.06.006

35. Liu J-H, Selinger LB, Cheng K-J, Beauchemin KA, Moloney MM (1997) Plant seed oil-bodies as an immobilization matrix for a recombinant xylanase from the rumen fungus Neocallimastix patriciarum. Mol Breed 3(6):463-470. doi:10.1023/ a:1009604119618

36. Liu J-R, Duan C-H, Zhao X, Tzen J, Cheng K-J, Pai C-K (2008) Cloning of a rumen fungal xylanase gene and purification of the recombinant enzyme via artificial oil bodies. Appl Microbiol Biotechnol 79(2):225-233. doi:10.1007/s00253-008-1418-1

37. Ludwig R, Appelhagen A (2005) Calculation of Clathrate-like water clusters including Buckminsterfullerene. Angew Chem Int Ed 44(5):811-815

38. Marcelja S, Radic N (1976) Repulsion of interfaces due to boundary water. Chem Phys Lett 42(1):129-130

39. McCaskill DR, Zhang F (1999) Use of rice bran oil in foods. Food Technol 53(2):50-52

40. Mulet X, Templer RH, Woscholski R, Ces O (2008) Evidence that phosphatidylinositol curved membrane interfaces. Langmuir 24 (16):8443-8447

41. Munnik T, Arisz SA, deVrije T, Musgrave A (1995) G protein activation stimulates phospholipase D signaling in plants. Plant Cell 7(12):2197-2210. doi:10.2307/3870162

42. Murgia S, Mele S, Monduzzi M (2003) Quantitative characterization of phospholipids in milk fat via P-31 NMR using a monophasic solvent mixture. Lipids 38(5):585-591. doi:10.1007/s11745-003-1500-3

43. Murphy DJ (2001) Biogenesis and functions of lipid bodies in animals, plants and microorganisms. Prog Lipid Res 40:325

44. Murphy DJ, Keen JN, Osullivan JN, Au DMY, Edwards EW, Jackson PJ, Cummins I, Gibbons T, Shaw CH, Ryan AJ (1991) A class of amphipathic proteins associated with lipid storage bodies in plants - possible similarities with animal serum apolipoproteins. Biochim Biophys Acta 1088(1):86-94

45. Naested H, Frandsen GI, Jauh GY, Hernandez-Pinzon I, Nielsen HB, Murphy DJ, Rogers JC, Mundy J (2000) Caleosins: $\mathrm{Ca} 2+-$ binding proteins associated with lipid bodies. Plant $\mathrm{Mol}$ Biol 44(4):463-476

46. Newgard CB, An J, Bain JR, Muehlbauer MJ, Stevens RD, Lien LF, Haqq AM, Shah SH, Arlotto M, Slentz CA, Rochon J, Gallup D, Ilkayeva O, Wenner BR, Yancy WS Jr, Eisenson H, Musante G, Surwit RS, Millington DS, Butler MD, Svetkey LP (2009) A branched-chain amino acid-related metabolic signature that differentiates obese and lean humans and contributes to insulin resistance. Cell Metab 9(4):311-326. doi:10.1016/j.cmet.2009.02.002

47. Nikiforidis CV, Kiosseoglou V (2009) Physicochemical stability of maize germ oil body emulsions as influenced by oil body surface -xanthan gum interactions. J Agric Food Chem 58(1):527-532. doi:10.1021/jf902544j

48. Pai JK, Siegel MI, Egan RW, Billah MM (1988) Phospholipase D catalyzes phospholipid metabolism in chemotactic peptidestimulated HL-60 granulocytes. J Biol Chem 263(25):12472-12477

49. Paris L, Cecchetti S, Spadaro F, Abalsamo L, Lugini L, Pisanu ME, Iorio E, Natali PG, Ramoni C, Podo F (2010) Inhibition of phosphatidylcholine-specific phospholipase $\mathrm{C}$ downregulates HER2 overexpression on plasma membrane of breast cancer cells. Breast Cancer Res 12(3):R27

50. Perera L, Essmann U, Berkowitz ML (1996) Role of water in the hydration force acting between lipid bilayers. Langmuir 12 (11):2625-2629

51. Plevin R, Stewart A, Paul A, Wakelam MJO (1992) Vasopressinstimulated H-3 inositol phosphate and H-3 phosphatidylbutanol accumulation in A10 vascular smooth muscle cells. Br J Pharmacol 107(1):109-115

52. Plietz P, Damaschun G, Müller JJ, Schwenke K-D (1983) The structure of 11-S globulins from sunflower and rape seed. Eur J Biochem 130(2):315-320. doi:10.1111/j.1432-1033.1983.tb07154.x

53. Potocky M, Elias M, Profotova B, Novotna Z, Valentova O, Zarsky V (2003) Phosphatidic acid produced by phospholipase D is required for tobacco pollen tube growth. Planta 217(1):122-130. doi:10.1007/s00425-002-0965-4 
54. Quehenberger O, Armando AM, Brown AH, Milne SB, Myers DS, Merrill AH, Bandyopadhyay S, Jones KN, Kelly S, Shaner RL, Sullards CM, Wang E, Murphy RC, Barkley RM, Leiker TJ, Raetz CRH, Guan Z, Laird GM, Six DA, Russell DW, McDonald JG, Subramaniam S, Fahy E, Dennis EA (2010) Lipidomics reveals a remarkable diversity of lipids in human plasma. JLipid Res 51 (11):3299-3305. doi:10.1194/jlr.M009449

55. Reichelt R, Schwenke K-D, König T, Pähtz W, Wangermann G (1980) Electron microscopic studies for estimation of the quaternary structure of the $11 \mathrm{~S}$ globulin (helianthinin) from sunflower seed (Helianthus annuus L.). Biochem Physiol Pflanz 175(7):653663. doi:10.1016/s0015-3796(80)80019-9

56. Rooijen GJH, Motoney MM (1995) Plant seed oil-bodies as carriers for foreign proteins. Nat Biotech 13(1):72-77

57. Rosivatz E, Woscholski R (2011) Removal or masking of phosphatidylinositol $(4,5)$ bisphosphate from the outer mitochondrial membrane causes mitochondrial fragmentation. Cell Signal 23 (2):478-486. doi:10.1016/j.cellsig.2010.10.025

58. Rüegg M, Moor U, Blanc B (1975) Hydration and thermal denaturation of $\beta$-lactoglobulin. A calorimetric study. Biochim Biophys Acta Protein Struct 400(2):334-342. doi:10.1016/0005-2795(75)90188-9

59. Schmid AC, Wise HM, Mitchell CA, Nussbaum R, Woscholski R (2004) Type II phosphoinositide 5-phosphatases have unique sensitivities towards fatty acid composition and head group phosphorylation. Fed Eur Biochem Soc Lett 576(1-2):9-13

60. Seddon JM (1990) Structure of the inverted hexagonal (Hii) phase, and non-lamellar phase-transitions of lipids. Biochim Biophys Acta 1031(1):1-69

61. Seddon JM, Templer RH (1995) Polymorphism of lipid-water systems. In: Lipowsky R, Sackman E (eds) The handbook of biological physics, vol I. Amsterdam, Elsevier Science

62. Shah SH, Bain JR, Muehlbauer MJ, Stevens RD, Crosslin DR, Haynes C, Dungan J, Newby LK, Hauser ER, Ginsburg GS, Newgard CB, Kraus WE (2010) Association of a peripheral blood metabolic profile with coronary artery disease and risk of subsequent cardiovascular events/clinical perspective. Circ: Cardiovasc Genet 3(2):207214. doi:10.1161/circgenetics.109.852814

63. Shearman GC, Ces O, Templer RH, Seddon JM (2006) Inverse lyotropic phases of lipids and membrane curvature. J Phys Condens Matter 18(28):S1105-S1124
64. Smith RJ, Justen JM, McNab AR, Rosenbloom CL, Steele AN, Detmers PA, Anderson DC, Manning AM (1996) U-73122: a potent inhibitor of human polymorphonuclear neutrophil adhesion on biological surfaces and adhesion-related effector functions. J Pharmacol Exp Ther 278(1):320-329

65. Su W, Yeku O, Olepu S, Genna A, Park J-S, Ren H, Du G, Gelb MH, Morris AJ, Frohman MA (2009) 5-Fluoro-2-indolyl deschlorohalopemide (FIPI), a phospholipase D pharmacological inhibitor that alters cell spreading and inhibits chemotaxis. Mol Pharmacol 75(3):437-446. doi:10.1124/mol.108.053298

66. Tzen JTC, Cao YZ, Laurent P, Ratnayake C, Huang AHC (1993) Lipids, proteins, and structure of seed oil bodies from diverse species. Plant Physiol 101(1):267-276

67. Tzen JTC, Huang AHC (1992) Surface-structure and properties of plant seed oil bodies. J Cell Biol 117(2):327-335

68. Tzen JTC, Lai YK, Chan KL, Huang AHC (1990) Oleosin isoforms of high and low-molecular weights are present in the oil bodies of diverse seed species. Plant Physiol 94(3):12821289

69. Tzen JTC, Lie GC, Huang AHC (1992) Characterization of the charged components and their topology on the surface of plant seed oil bodies. J Biol Chem 267(22):15626-15634

70. Tzen JTC, Peng C-C, Cheng D-J, Chen ECF, Chiu JMH (1997) A new method for seed oil body purification and examination of oil body integrity following germination. J Biochem 121(4):762-768

71. Wood K, Frölich A, Paciaroni A, Moulin M, Härtlein M, Zaccai G, Tobias DJ, Weik M (2008) Coincidence of dynamical transitions in a soluble protein and its hydration water: direct measurements by neutron scattering and MD simulations. J Am Chem Soc 130 (14):4586-4587. doi:10.1021/ja710526r

72. Zhao Y, Yan A, Feijo J, Furutani M, Takenawa T, Hwang I, Fu Y, Yang Z (2010) Phosphoinositides regulate clathrin-dependent endocytosis at the tip of pollen tubes in Arabidopsis and tobacco. The Plant Cell Online. doi:10.1105/tpc. 110.076760

73. Zoncu R, Perera RM, Sebastian R, Nakatsu F, Chen H, Balla T, Ayala G, Toomre D, De Camilli PV (2007) Loss of endocytic clathrin-coated pits upon acute depletion of phosphatidylinositol 4,5-bisphosphate. Proc Natl Acad Sci 104(10):3793-3798. doi:10.1073/pnas.0611733104 